\title{
Impact of Roux-en-Y gastric bypass on lipid and inflammatory profiles
}

\section{Impacto da derivação gástrica em Y-de-Roux no perfil inflamatório e lipídico}

\author{
Cleiton da Silva Oliveira'; Bruna Teles Soares Beserra²; Raphael Salles Granato Cunha1; Ana Gabriela Estevam Brito3; \\ Rafaella Cristina Dimbarre de Miranda ${ }^{1}$; Lúcia Andréia Zanette Ramos Zenili; Everson Araújo Nunes ${ }^{5}$; Erasmo Benicio Santos de \\ MORAES TRINDADE ${ }^{5}$
}

A $B$ S T R A A C T

\begin{abstract}
Objective: To evaluate the behavior of acute phase proteins and lipid profile in patients undergoing Roux-en-Y gastric bypass. Methods: We conducted a prospective study, consisting of three moments: M1 - preoperative (24 hours before surgery); M2 - 30 days after surgery; and M3 - 180 days after surgery. We carried measured height and BMI, as well as determined the concentrations of acute phase proteins (C-reactive protein (CRP), albumin and Alpha-1-acid glycoprotein) and total cholesterol, LDL-C, HDL-C and triacylglycerol. Results: participants comprised 25 individuals, with a mean age of $39.28 \pm 8.07,72 \%$ female. At all times of the study there was statistically significant difference as for weight loss and BMI. We found a significant decrease in CRP concentrations between the moments M1 and M3 $(p=0.041)$ and between $M 2$ and $M 3(p=0.018)$. There was decrease in Alpha-1-GA concentrations between M1 and M2 ( $p=0.023)$ and between M1 and M3 ( $p=0.028)$. The albumin values increased, but did not differ between times. Total cholesterol and triacylglycerol decreased significantly ay all times. LDL-c concentrations decreased and differed between M1 and M2 ( $p=0.001)$ and between M1 and M3 ( $p=0.001)$. HDL-c values increased, however only differing between $M 1$ and M2 ( $p=0.050)$. Conclusion: Roux-en-Y gastric bypass promoted a decrease in plasma concentrations of CRP and Alpha-1-acid glycoprotein, improving lipid and inflammatory profiles.
\end{abstract}

Key words: Gastric Bypass. Obesity. Inflammation Mediators. Weight Loss

\section{INTRODUCTION}

O besity is defined as abnormal or excessive fat accumulation and can harm one's health'. It is a noncommunicable chronic disease ${ }^{2}$. Considered worldwide a public health problem, it continues to increase in prevalence, both in developed countries, as in developing ones ${ }^{35}$. In Brazil, the prevalence of obesity in men and women aged 20 years or older is $12.5 \%$ and $16.9 \%$, respectively. The country Southern Region has a higher prevalence of obesity when compared to other regions ${ }^{6}$.

The treatment of obesity is complex and multidisciplinary. There are different kinds of treatments, which are non-pharmacological, pharmacological and surgical. These treatments seek a lasting reduction and maintenance of body weight up to levels considered clinically satisfactory, with beneficial effects on possible associated diseases as type 2 diabetes, hypertension and dyslipidemia?.

Regarding surgical treatment, Roux en $Y$ gastric bypass (RYGB) reduces the stomach capacity and concomitantly alters the production of hormone responsible for regulating hunger and satiety ${ }^{8}$. Currently, this operation has been the most frequently performed in Brazil, corresponding to 75\% of total operations employed for the treatment of obesity $^{9}$

It is worth mentioning that the obese individual is considered a having a chronic low-grade inflammatory condition $^{10}$. In this scenario are present the acute phase proteins (APP), defined as those whose plasma concentration range at least 25\% when an inflammatory response ensues, and can be categorized as negative when normal values are reduced during inflammation, and positive, wherein normal values are increased within inflammation ${ }^{11,12}$. Produced mainly by hepatocytes, APP may also be synthesized on immune cells, epithelial cells and adipocytes ${ }^{11}$.

Given the above, this study aims to evaluate the behavior of APP (C-reactive protein, Alpha-1acid glycoprotein and albumin) and lipid profile in patients undergoing RYGB.

1. Departamento de Nutrição / Universidade Federal de Santa Catarina; 2. Programa de Pós-Graduação em Nutrição / Universidade Federal de Santa Catarina; 3. Hospital Universitário Professor Polydoro Ernani de São Thiago / Universidade Federal de Santa Catarina; 4. Departamento de Fisiologia / Universidade Federal de Santa Catarina; 5. Programa de Pós-Graduação em Nutrição / Universidade Federal de Santa Catarina. 


\section{METHODS}

We conducted a prospective study in a public hospital that is reference for bariatric surgery. We evaluated patients undergoing Roux-en-Y gastric bypass. The study was approved by the Ethics in Human Research Committee under number 2422/2011. In addition, this survey was conducted in accordance with the resolution of the National Health Council no 466 of 12/12/2012. All individuals involved in this study were informed and signed an Informed Consent form. There were no conflicts of interest.

The study consisted of three moments: M1 preoperative time ( 24 hours before surgery); $\mathrm{M} 2-30$ days after surgery; and M3 - 180 days after surgery. The times were chosen according to the outpatient treatment protocol for patients undergoing bariatric surgery in that hospital. Clinical and epidemiological variables recorded were age, gender, use of drugs, associated diseases and smoking. All these data were collected through interviews.

For the assessment of nutritional status we carried out anthropometric measurements of weight and height. The nutritional status was classified by body mass index (BMI) using the cutoff points defined by the World Health Organization $(\mathrm{WHO})^{13}$

Regarding the laboratory variables, the examinations related to this study were collected in the proposed times. Study participants were asked to follow an overnight fast of 12 hours. Blood samples were collected by venipuncture in the ulnar region of the forearm, using vacuum tubes. Then the blood was centrifuged and processed in the hospital Clinical Analysis Service. Laboratory parameters included measurement of C-reactive protein (CRP), alpha 1-acid glycoprotein (Alpha 1-AG), albumin and lipid profile. CRP was determined by immunonephelometry method ${ }^{14}$ (DadeBehring Siemens Inc., Newark, DE, USA), alpha 1 AG, also by immunonephelometry ${ }^{15}$ (DadeBehring Siemens Inc., Newark, DE, USA) and albumin, by the automated colorimetric method (Siemens Healthcare Diagnostics Inc., Newark, DE, USA) employing bromcresol purple as color reagent ${ }^{14}$. Total cholesterol ${ }^{16}, \mathrm{HDL}$-cholesterol ${ }^{17}$ and triglycerides ${ }^{17}$ were determined by enzymatic method. LDLcholesterol was determined using the Friedewald equation ${ }^{18}$ (LDL-C $=$ Total cholesterol - HDL-C Triglycerides / 5) wherein triglycerides / 5 represents the VLDL C.

The reference value used in that hospital for $\mathrm{CRP}$ is $<3.3 \mathrm{mg} / \mathrm{L}$, and alpha-1-GA, distinguishing as to gender, are: Women: $40-120 \mathrm{mg} / \mathrm{dL}$; men: $50-130 \mathrm{mg} /$ $\mathrm{dL}$. The reference adopted for albumin is 3.4 to $5.0 \mathrm{~g} / \mathrm{dL}$. Reference values for total cholesterol: Desirable: $<200$ mg/dL; borderline: 200-239 mg/dL; High: $\geq 240 \mathrm{mg} / \mathrm{dL}$. Reference values for HDL-c: low: < $40 \mathrm{mg} / \mathrm{dL}$; high: $>60 \mathrm{mg} / \mathrm{dL}$. Reference values for LDL-C: good: < $100 \mathrm{mg} /$ $\mathrm{dL}$; desirable: between 100 and $129 \mathrm{mg} / \mathrm{dL}$; borderline: between 130 and $159 \mathrm{mg} / \mathrm{dL}$; high: between 160 and 189 $\mathrm{mg} / \mathrm{dL}$; too high: $\geq 190 \mathrm{mg} / \mathrm{dL}$. Reference values for triacylglycerol: good: < $150 \mathrm{mg} / \mathrm{dL}$; borderline: 150200 mg/dL; High: 201-499 mg/dL; too high: $\geq 500$ mg/dL. The adopted classification values for complications risk were: no risk: $<0.4$; low risk: 0.4-1.2; medium risk: 1.22.0; high risk: $>2.0^{19}$.

The sample consisted of patients aged between 18 and 60 years undergoing RYGB. The study included individuals of both genders in the preoperative phase of bariatric surgery at the hospital. We did not include individuals with inability to perform the biochemical and anthropometric measurements and who did not sign the informed consent.

To evaluate the symmetry of variables we considered the coefficient of variation and the Shapiro-Wilk test ( $p$ values $<0.05$ are considered asymmetrical variables). Data were presented as mean and standard deviation for symmetrical variables and median and interquartile range for asymmetric variables. The paired $t$ test and the Wilcoxon test for paired data were used to test the differences between the different moments of the study, considering $\mathrm{p}$ $<0.05$ for statistical significance.

\section{RESULTS}

The study included 25 patients with a mean age of 39.2 ( \pm 8.07 ) years. Most participants were female (72\%) and with comorbidities related to obesity, such as hypertension (44\%), type 2 diabetes mellitus (23.5\%) and dyslipidemia (5.9\%). All patients were taking some kind of medication, among which stand out hydrochlorothiazide $(11.5 \%)$, metformin hydrochloride $(11.5 \%)$ and losartan (9.6\%). During follow-up there were participants losses, 13 at 30 days and 14 at 180 days; absence to appointments was the main reason for losses.

We observed an average percentage weight loss of $14.14 \%$ at 30 days and the same average of $28.74 \%$ at 180 days. In all stages of the study there was a significant reduction in weight, $\mathrm{BMI}$, triglyceride and total cholesterol $(p<0.05)$ (Table 1). LDL-c concentrations decreased and differ between $M 1$ and $M 2(p=0.001)$ and $M 1$ and $M 3$ ( $p=0.001)$, while the HDL-c values increased with statistically significant difference only between $\mathrm{M} 1$ and M2 ( $p=0.049)$ (Figure 1). The acute phase protein alpha$1-G A$ also had its serum concentrations reduced ( $p=$ 0.028). Albumin concentrations, on their turn, showed an increase, but without significant differences (Table 1). CRP showed an inverse behavior in the two study periods, that is, increased between $M 1$ and $M 2(p<0.05)$ and significantly decreased between $\mathrm{M} 2$ and $\mathrm{M} 3$ ( $p<0.05$ ). The CRP / Albumin ratio showed a change of behavior in the relationship of these proteins, in which participants had the degree of complication shifted from high risk to low risk (Figure 1). 
Table 1- Anthropometric and biochemical parameters of the study participants.

\begin{tabular}{|c|c|c|c|c|c|c|c|}
\hline \multirow{2}{*}{$\begin{array}{l}\text { Variables } \\
\text { Weight * }\end{array}$} & \multicolumn{2}{|c|}{$\begin{array}{c}\text { Moment } 1(n=25) \\
\text { Mean } \pm D P\end{array}$} & \multicolumn{2}{|c|}{$\begin{array}{c}\text { Moment } 2(n=12) \\
\text { Mean } \pm D P\end{array}$} & \multicolumn{3}{|c|}{$\begin{array}{c}\text { Moment } 3(n=11) \\
\text { Mean } \pm D P\end{array}$} \\
\hline & 121.52 & $23.74^{a}$ & $105.42 \pm$ & $18.41^{b}$ & 86.56 & \pm & $17.06^{c}$ \\
\hline $\mathrm{BMI}^{*}$ & 49.71 & $7.66^{a}$ & $41.57 \pm$ & $5.47^{b}$ & 33.43 & \pm & $5.29 c$ \\
\hline Total cholesterol* & 201.20 & $43.21^{\mathrm{a}}$ & $173.90 \pm$ & $29.76^{b}$ & 149.67 & \pm & $40.55^{c}$ \\
\hline HDL-cholesterol* & 36.88 & $10.17^{a}$ & $31.54 \pm$ & $7.93^{\mathrm{b}}$ & 41.67 & \pm & $10.97^{a-b}$ \\
\hline LDL cholesterol* & 136.76 & $\pm \quad 35.62^{\mathrm{a}}$ & $112.27 \pm$ & $22.83^{b}$ & 93.30 & \pm & $28.65^{b}$ \\
\hline Triacylglycerol** † & \multicolumn{2}{|c|}{$144(110-187)^{a}$} & 117 & $(105-131)^{b}$ & \multicolumn{3}{|c|}{$74.00(54.50-91.50)$} \\
\hline Alpha-1-GA ** † & \multicolumn{2}{|c|}{$104.99(86.2-116)^{a}$} & 127 & $(122-168)^{b}$ & 69.90 & \multicolumn{2}{|c|}{$(58.2-91.3)^{b}$} \\
\hline Albumin* & 3.64 & $\pm \quad 0.25$ & $3.70 \pm$ & 0.20 & 3.72 & \pm & 0.22 \\
\hline
\end{tabular}

Alpha-1-GA - Alpha-1-acid glycoprotein; CRP - C-reactive protein; Data that do not share the same letter within a horizontal row are significantly different $(p<0.05)$. * Paired t test, ** Wilcoxon test for paired data. + Results are expressed as median and interquartile range.

\section{DISCUSSION}

In this study, the average age and the high prevalence of females are similar to other studies that analyzed the inflammatory profile in patients undergoing surgical treatment of obesity ${ }^{20-22}$. The predominance of women may be justified by a higher obesity prevalence when compared to men in the world ${ }^{4}$.

Overweight and obesity are associated with increased risk of developing certain metabolic abnormalities such as type 2 diabetes mellitus, dyslipidemia and cardiovascular diseases such as hypertension. The origin of these comorbidities was initially attributed to hyperinsulinemia or insulin resistance. However, chronic elevations in the concentration of adipokines, such as tumor necrosis factor (TNF), play an important role in the development of metabolic complications associated with obesity ${ }^{10}$. According to a meta-analysis by Guh et al. ${ }^{23}$, the risks of developing type 2 diabetes and hypertension, are respectively 12.41 (95\% Cl 9.03-17.06) and 2.42 (95\% Cl 1.59-3.67) times higher among women who are obese than among those who are not, rendering obesity as an aggravating factor of such diseases in women. In another meta-analysis ${ }^{24}$ that analyzed the effectiveness and adverse surgical treatment of obesity events, the prevalence of individuals preoperatively diagnosed with type 2 diabetes mellitus who showed improvement or resolution of symptoms after surgery ranged from $64 \%$ to $100 \%$ (median 100\%). When hypertension was analyzed by studies, $38 \%$ (ranging from $16 \%$ to $83 \%$ ) of patients had hypertension preoperatively, of whom $25 \%$ to $100 \%$ (median $89 \%$ ) showed improvement or resolution of this condition, resulting in improvement range of 95\% to $100 \%$ (median $100 \%$ ). In studies on dyslipidemia, 32\% (range 3\% to $65 \%$ ) of subjects had this comorbidity preoperatively, of whom $60 \%$ to $100 \%$ (median $88 \%$ ) reported improvement or resolution of dyslipidemia in moments subsequent to the surgical procedure ${ }^{24}$.
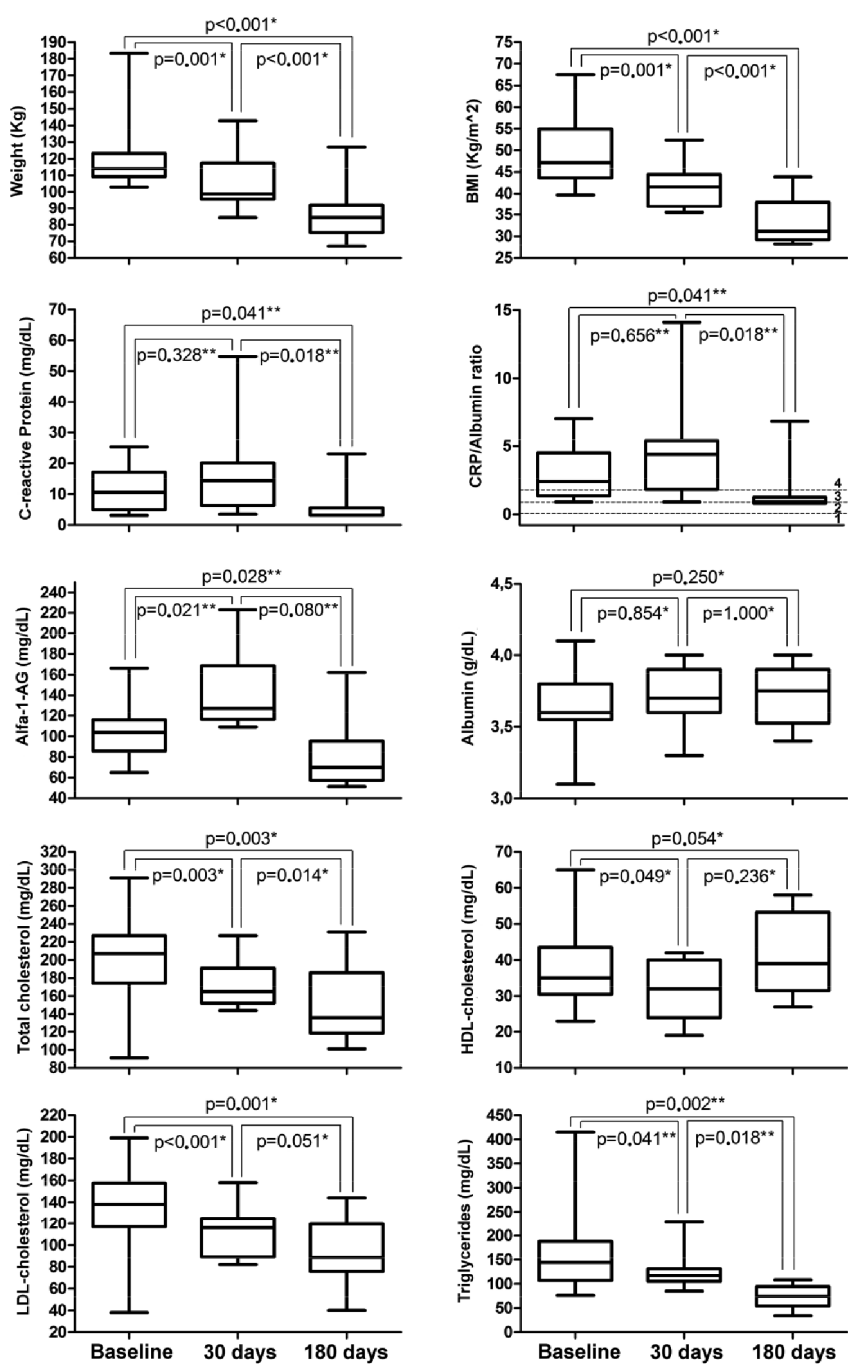

Figure 1 - Distribution of weight, BMI, CRP acute phase protein and its relationship with albumin, Alpha-1-GA, albumin total cholesterol and HDL-cholesterol in the different moments of the study.

* Wilcoxon test for paired data. Categories: 1- without risk; 2 low risk; 3- medium risk; 4-high risk. Significant difference: $p<0.05$. 
During the time of the study, weight and BMI decreased significantly, achieving both a reduction $>20 \%$ at 180 days, which corroborates the findings of other studies that analyzed the impact of surgical obesity treatment on these variables ${ }^{20,22}$ and demonstrates the effectiveness of this procedure as to loss of body weight. The reduction in body weight also seems to improve the inflammatory condition in the obese individual, specifically reducing pro-inflammatory markers (CRP, TNF- $\alpha$, IL- 6 and leptin) and increasing an anti-inflammatory marker (adiponectin), as concluded Forsythe et al. in a review ${ }^{25}$. Moreover, the same review reports that the largest and most consistent improvements are observed in those studies in which the subjects had at least a $10 \%$ weight loss 25 , which occurred in the present study from the 30th postoperative day on.

Weight reduction in obese subjects and its relation with the decrease of serum cholesterol render it difficult to estimate the reduction of the latter is primarily due to the reduced synthesis or lower absorption, since a metabolic pathway or another will result in compensatory measures to maintain cholesterol homeostasis ${ }^{26}$. Similar to the present study, in which Total Cholesterol (TC), Triglycerides (TG) and LDL-C were reduced with statistical difference after 180 days of operation, the study by Pedrosa et al. ${ }^{27}$, who analyzed the lipid profile of patients undergoing Roux-en-Y gastric bypass, showed that after one year postoperatively there was a significant decrease in serum concentrations of TC, LDL-C and TG, and increased HDL-C. However, in this study, HDL c was increased at 180 days compared with the preoperative period, but without significant differences. Possibly, the determining factor was the time of analysis; if the study continued longer than 180 days, perhaps it would display a difference. Thus, the loss of weight after RYGB appears to limit the absorption of cholesterol ${ }^{26}$, with consequent negative equilibrium of the same and reduction in total cholesterol and LDL-c. This low absorption and decrease in total cholesterol synthesis in the body may contribute to the postoperative reduction of cardiovascular risk $^{26}$.

The CRP synthesis in the liver occurs primarily by the action interleukin-6 (IL-6), the adipocytes being responsible for producing about $30 \%$ of circulating IL- 6 of non-inflammatory origin. The weight loss and consequent reduction of the fatty tissue caused by RYGB results in lower serum IL-6 concentrations, reduced CRP hepatic synthesis and consequent reduction in the deleterious biological effects of this protein ${ }^{21,22}$. Some studies confirm this theory by showing that 180 days after surgery, in addition to significant weight loss, there is also reduction in CRP20,22,28,29. In a systematic review, Selvin et al.. ${ }^{30}$ showed that each kilogram of body weight lost through modification of diet and lifestyle corresponded to a $0.13 \mathrm{mg} / \mathrm{L}$ reduction in CRP concentration; however, weight loss induced by bariatric surgery provoked a higher decrease, of $0.16 \mathrm{mg} / \mathrm{L}$ by $\mathrm{Kg}$ lost, indicating more effectiveness of the surgical treatment on reducing inflammatory markers compared with weight loss through diet and lifestyle changes.

For Alpha 1-AG, it is known to be an indicator of tissue injury of inflammatory or infectious character, and its hepatic synthesis is stimulated by cytokines such as IL-1, IL6 , leptin and TNF- $\alpha$, which are mostly secreted by adipocytes ${ }^{21}$. In the study of John Cabrera et al. ${ }^{21}$, Alpha 1AG was positively correlated with CRP in the RYGB pre- and postoperative periods. The authors believe that the loss of adipose tissue and consequent reduction in the synthesis of cytokines may explain the positive correlation found, suggesting that this protein may be used as a marker of inflammation in obesity. As in this study, Anty et al..$^{31}$ and lannelli et al. ${ }^{32}$ also observed a significant reduction of Alpha 1AG after weight loss induced by surgical treatment, with a reduction in the inflammatory profile of the individual.

Albumin is considered a negative APP. The reduction in the synthesis of APP is believed to occur by increased need for amino acid for synthesis of positive APP and other inflammatory mediators ${ }^{11}$. Also, during the inflammatory process, some changes occur in vascular permeability resulting in loss of albumin to extravascular medium and consequent rapid drop in plasma concentrations ${ }^{33}$. In the present study there was no significant difference in the concentration of albumin in the analyzed moments. Similarly, other studies have also found non-impressive results. Farias et al. ${ }^{34}$ analyzed the serum albumin of women undergoing RYGBand observed a low percentage of individuals with hypoalbuminaemia $(12.5 \% ; n=1)$ after eight months. Nicoletti et al. ${ }^{35}$ reported a reduction in serum albumin just 12 months after surgery, there being no difference in times three and six months, and suggested that serum albumin cannot be an effective indicator of the protein profile in post bariatric surgery time.

The median CRP / Albumin ratio, which indicates the of risk of inflammatory stress complications ${ }^{19}$, was at its highest degree in the preoperative moment (M1) and 30 days after surgery (M2). However, at 180 days (M3) the median of this ratio was ranked among medium and low risk for complications. This variation can be attributed to the possible inflammatory state caused by the surgical procedure, which tends to regress not earlier than three months after surgery 22 .

It is noteworthy that the study sample sustained a large loss of patients during follow-up, for reasons expected as sample characteristics studied, making the sample small. The 180-day follow-up period, while being the most critical period and of major changes for patients undergoing RYGB, is still a short period when it comes to a major surgical procedure. Such factors can be considered as limitations of the study.

Thus, we conclude that in the sample studied RYGB induced weight loss and reduction of BMI, total cholesterol and triacylglycerol, also causing a decrease in concentrations of CRP and Alpha-1-acid glycoprotein, and consequently improving lipid and inflammatory profile. 


\title{
R E S U M O
}

\begin{abstract}
Objetivo: avaliar o comportamento das proteínas de fase aguda e o perfil lipídico em pacientes submetidos à derivação gástrica em Y-de-Roux. Métodos: estudo prospectivo, constituído por três momentos: M1 - pré-cirúrgico (24 horas antes do procedimento cirúrgico); M2 - 30 dias pós-cirúrgico; e M3 - 180 dias pós-cirúrgico. Foram realizadas aferição antropométrica de peso, altura e IMC, como também determinação das concentrações das proteínas de fase aguda (proteína c reativa (PCR), albumina e alfa-1-glicoproteínaácida) e de colesterol total, LDL-C, HDL-c e triacilglicerol. Resultados: participaram desse estudo 25 indivíduos, com média de idade de $39,28 \pm 8,07$, sendo $72 \%$ do sexo feminino. Em todos os momentos do estudo observou-se diferença estatística significativa quanto à redução de peso e IMC. Verificou-se diminuição com diferença nas concentrações da PCR entre os momentos M1 e M3 $(p=0,041) ; M 2$ e $M 3$ ( $p=0,018)$. As concentrações da a1-GA reduziram e foram diferentes entre os momentos $M 1$ e $M 2$ ( $p=0,023)$; M1 e M3 $(p=0,028)$. Os valores de albumina aumentaram, mas não diferiram entre os momentos. O colesterol total e o triacilglicerol diminuíram com diferença entre todos os momentos. As concentrações de LDL-c diminuíram e diferiram entre os momentos M1 e M2 ( $p=0,001) ; M 1$ e M3 ( $p=0,001)$. Os valores de HDL-c aumentaram, entretanto apenas diferiram entre os momentos M1 e M2 $(p=0,050)$. Conclusão: a derivação gástrica em Y-de-Roux promoveu diminuição nas concentrações plasmáticas da $P C R$ e alfa-1glicoproteína ácida, melhorando o perfil inflamatório e lipídico.
\end{abstract}

Descritores: Derivação Gástrica. Obesidade. Mediadores da Inflamação. Perda de Peso.

\section{REFERENCES}

1. World Health Organization [homepage na internet]. Fact sheet $n^{\circ}$ 311: Facts about overweight and obesity. Acessado em: 15 mar 2013. Disponível em: http://www.who.int/mediacentre/factsheets/ fs311/en/

2. Francischi RPP, Pereira LO, Freitas CS, Klopfer M, Santos RC, Vieira $P$, et al. Obesidade: atualização sobre sua etiologia, morbidade e tratamento. Rev Nutr. 2000;13(1):17-28.

3. Pinheiro ARO, Freitas SFT, Corso ACT. Uma abordagem epidemiológica da obesidade. Rev Nutr. 2004;17(4):523-33.

4. World Health Organization. Obesity: prevention and management of the global epidemic. Reportof a WHO Consultation on Obesity. Geneva: WHO. 1998.

5. Abrantes MM, Lamounier JA, Colosimo EA. Prevalência de sobrepeso e obesidade nas regiões Nordeste e Sudeste do Brasil. Rev Assoc Med Bras. 2003;49(2):162-6.

6. Instituto Brasileiro de Geografia e Estatística. Pesquisa de orçamentos familiares 2008-2009. Antropometria e Estado Nutricional de Crianças, adolescentes e adultos no Brasil. Rio de Janeiro: IBGE, 2010.

7. Associação Brasileira para o Estudo da Obesidade e da Síndrome Metabólica. Diretrizes Brasileiras de Obesidade 2009/2010 / ABESO - Associação Brasileira para o Estudo da obesidade e da Síndrome Metabólica. 3a ed. Itapevi, SP: AC Farmacêutica, 2009.

8. Brasil. Conselho Federal de Medicina. Resolução CFM no 1.942/ 2010. Normas seguras para o tratamento cirúrgico da obesidade mórbida, definindo indicações, procedimentos e equipe. Diário Oficial da União, 12 fev 2010; Seção I, p. 72

9. Sociedade Brasileira de Cirurgia Bariátrica e Metabólica [homepage na internet]. Técnicas Cirúrgicas. Acessado em: 27 fev 2013. Disponível em: http://www.sbcbm.org.br/wordpress/tratamento-cirurgico/cirurgia-laparoscopica/

10. Bulló M, Casas-Agustench P, Amigó-Correig P, Aranceta J, SalasSalvadó J. Inflammation, obesity and comorbidities: the role of diet. Public Health Nutr. 2007:10(10A):1164-72.

11. Gabay C, Kushner I. Acute-phase proteins and other systemic responses to inflammation. N Engl J Med. 1999;340(6):448-54.

12. Morley JJ, Kushner I. Serum C-reactive protein levels in disease. Ann N Y Acad Sci. 1982:389:406-18.

13. World Health Organization [homepage na internet]. BMI classification, Geneve, Switzerland: World Health Organization, 2008 [acesso em 16 mar 2013]. Disponível em: http://apps.who.int/ bmi/index.jsp?introPage=intro_3.html

14. Lasky FD, Li ZM, Shaver DD, Savory J, Sarvory MG, Willey DG, et al. Evaluation of a bromocresol purple method for the determination of albumin adapted to the DuPont aca discrete clinical analyzer. Clin Biochem. 1985;18(5):290-6.

15. Ledue TB, Weiner DL, Sipe JD, Poulin SE, Collins MF, Rifai N Analytical evaluation of particle-enhanced immunonephelometric assays for C-reactive protein, serum amyloid $A$ and mannosebinding protein in human serum. Ann Clin Biochem. 1998;35 (Pt 6):745-53.

16. Rautela GS, Liedtke RJ. Automated enzymic measurement of total cholesterol in serum. Clin Chem. 1978;24(1):108-14.

17. Rifai N, Russell Warnick G, Dominiczak MH. Handbook of Lipoprotein Testing. Washington, DC: AACC; 1997.

18. Friedewald WT, Levy RI, Fredrickson DS. Estimation of the concentration of low-density lipoprotein cholesterol in plasma, without use of the preparative ultracentrifuge. Clin Chem. 1972;18(6):499-502.

19. Correa CR, Angeleli AYO, Camargo NR, Barbosa L, Burini RC. Comparação entre a relação $\mathrm{PCR} /$ albumina e o índice de prognóstico inflamatório nutricional (IPIN). J Bras Patol Med Lab. 2002;38(3):18390

20. Holdstock C, Lind L, Engstrom BE, Ohrvall M, Sundbom M, Larsson $A$, et al. CRP reduction following gastric bypass surgery is most pronounced in insulin-sensitive subjects. Int J Obes. 2005;29(10):1275-80.

21. João Cabrera E, Valezi AC, Delfino VD, Lavado EL, Barbosa DS Reduction in plasma levels of inflammatory and oxidative stress indicators after Roux-en-Y gastric bypass. Obes Surg. 2010;20(1):42-9

22. Miller GD, Nicklas BJ, Fernandez A. Serial changes in inflammatory biomarkers after Roux-en-Y gastric bypass surgery. Surg Obes Relat Dis. 2011;7(5):618-24.

23. Guh DP, Zhang W, Bansback N, Amarsi Z, Birmingham CL, Anis AH. The incidence of co-morbidities related to obesity and overweight: a systematic review and meta-analysis. BMC Public Health. 2009.9:88

24. Maggard MA, Shugarman LR, Suttorp $M$, Maglione $M$, Sugerman $\mathrm{HJ}$, Livingston $\mathrm{EH}$, et al. Meta-analysis: surgical treatment of obesity. Ann Intern Med. 2005;142(7):547-59.

25. Forsythe LK, Wallace JM, Livingstone MB. Obesity and inflammation: the effects of weight loss. Nutr Res Rev. 2008;21(2):117-33.

26. Pihlajamäki J, Grönlund S, Simonen M, Käkelä $P$, Moilanen L, Pääkkönen $M$, et al. Cholesterol absorption decreases after Rouxen-Y gastric bypass but not after gastric banding. Metabolism. 2010:59(6):866-72.

27. Pedrosa IV, Burgos MGPA, Souza NC, Morais CN. Aspectos nutricionais em obesos antes e após a cirurgia bariátrica. Rev Col Bras Cir. 2009;36(4):316-22 
28. Pardina E, Ferrer R, Baena-Fustegueras JA, Rivero J, Lecube A, Fort JM, et al. Only C-reactive protein, but not TNF-á or IL6, reflects the improvement in inflammation after bariatric surgery. Obes Surg. 2012;22(1):131-9.

29. Rojas P, Carrasco F, Codoceo J, Inostroza J, Basfi-fer K, Papapietro $K$, et al. Trace element status and inflammation parameters after 6 months of Roux-en-Y gastric bypass. Obes Surg. 2011;21(5):5618.

30. Selvin E, Paynter NP, Erlinger TP. The effect of weight loss on Creactive protein: a systematic review. Arch Intern Med. 2007; 167(1):31-9.

31. Anty R, Dahman M, lannelli A, Gual P, Staccini-Myx A, Amor IB, et al. Bariatric surgery can correct iron depletion in morbidly obese women: a link with chronic inflammation. Obes Surg. 2008;18(6):709-14.

32. Iannelli A, Anty R, Piche T, Dahman M, Gual P, Tran A, et al. Impact of laparoscopic Roux-en-Y gastric bypass on metabolic syndrome, inflammation, and insulin resistance in super versus morbidly obese women. Obes Surg. 2009;19(5):577-82.
33. Santos NSJ, Draibe SA, Kamimura MA, Cuppari L. Albumina sérica como marcador nutricional de pacientes em hemodiálise. Rev Nutr. 2004;17(3):339-49.

34. Farias LM, Coêlho MPSS, Barbosa RF, Santos GS, Marreiro DN. Aspectos nutricionais em mulheres obesas submetidas à gastroplastia vertical com derivação gastro-jejunal em Y-de- Roux. Rev Bras Nutr Clin. 2006;21(2):98-103.

35. Nicoletti CF, Morandi Junqueira-Franco MV, dos Santos JE, Marchini JS, Salgado W Jr, Nonino CB. Protein and amino acid status before and after bariatric surgery: a 12-month follow-up study. Surg Obes Relat Dis. 2013;9(6):1008-12.

Received at: 25/10/2014

Accepted for publication: 10/01/2015

Conflict of interest: none.

Source of funding: none.

\section{Mailing address:}

Erasmo Benício Santos Moraes Trindade

E-mail: erasmotrindade@gmail.com 